\title{
ON THE VARIABILITY
}

\section{OF THE SALTING-OUT CURVES OF PROTEINS OF NORMAL HUMAN PLASMA AND SERUM*}

\author{
by \\ ELIZABETH P. STEYN-PARVE \\ Laboratory for Physiological Chemistry, The University, Utrecht (Netherlands) \\ AND \\ A. J. VAN DEN HOUT \\ Surgical Department of the University, Utrecht (Netherlands)
}

\section{INTRODUCTION}

The refined method of salting out proteins elaborated by DERRIEN ${ }^{1}$ permits us to distinguish $I 8$ to 22 components, globulins and albumins, when it is applied to blood serum according to the so-called routine technique. It is therefore one of the most sensitive methods for investigating protein mixtures. It also clearly reveals the more serious disorders in protein composition of certain pathological human sera ${ }^{2,3}$.

The question arose whether it could also be used to detect smaller deviations from normal, such as were thought to exist in blood plasma of patients undergoing or having undergone certain operations, whose condition often requires numerous blood transfusions. To answer this question it was necessary to know the extent of normal variations, so the variability in time has been studied of diagrams of plasma proteins of normal individuals. This investigation, described below, has shown that the diagrams obtained from normal individuals are influenced by a number of factors: the manner of withdrawing the blood, the anti-coagulant used, the presence or absence of fibrinogen and the non-protein components of the plasma. Apart from these influences the curves of different individuals do not only differ from one another, but also change rapidly and markedly with time, so the circulating plasma proteins appear to be in a highly dynamic state.

\section{EXPERIMENTAL}

\section{Materials and methods}

Blood was withdrawn from the cubital vein of fasting test persons with light stasis and collected in $50 \mathrm{ml}$ Erlenmeyer flasks. For preparation of plasma, roo mg sodium citrate in $0.2 \mathrm{ml} \mathrm{H}_{2} \mathrm{O}$ was usually employed as anti-coagulant. For preparation of serum, blood was either allowed to clot and placed at $37^{\circ} \mathrm{C}$ for 4 hours, followed by 20 hours at $2^{\circ} \mathrm{C}$, or defibrinated by stirring with a glass rod. Centrifugation took place for 30 minutes at $1800-2000$ r.p.m.

" A summary of this work has been presented before the IInd International Congress of Biochemistry, Paris, July r952.

References $p .325$. 
Dialysis of plasma took place during 24 hours at $2^{\circ} \mathrm{C}$ in cellophane tubing against physiological saline containing $0.3 \%$ sodium citrate, which was frequently renewed.

Salting out was performed according to DERRIEN's indications ${ }^{1}$. A $3.5 \mathrm{M}$ equimolecular mixture of primary and secondary potassium phosphate was used as stock salt solution. Protein filtrates were analyzed by micro-Kjeldahl nitrogen determination. All results are plotted in derived curves $-\left(\frac{\Delta S}{\Delta C}\right) \cdot i=\mathrm{f}(C)$, in which $\Delta S$ is the difference in nitrogen content of two consecutive filtrates, $C$ is the salt concentration and $i$ the increment of salt concentration of consecutive samples: $1.2 \%$ of the $3.5 M$ stock salt solution. In all experiments $\Delta C$ was equal to $i$.

\section{Results}

Diagrams of serum of one person, established with several weeks' interval, showed many variations in detailed structure. Fig. I gives one example of the several persons thus investigated.

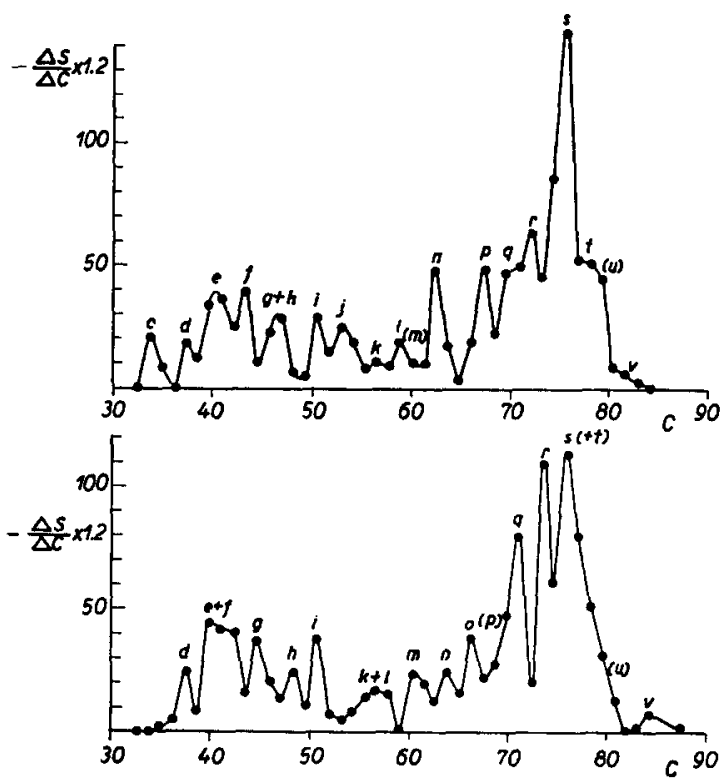

Fig. I. "Derived" salting-out curves of a normal man, established with 2 weeks' interval. Abscissa: salt concentration in percentage $3.5 M$ potassium phosphate, $\mathrm{pH}$ 6.5. Ordinate: $-\frac{\Delta S}{\Delta C} \times \mathbf{I . 2}=$ change in nitrogen content of consecutive protein filtrates, expressed in $\gamma$ nitrogen. $\Delta C=\mathrm{I} .2$.

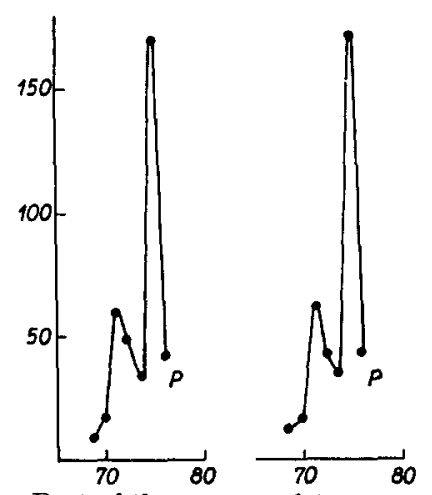

Fig. 2. Part of the curves of two samples of plasma, prepared from blood samples withdrawn rapidly one after the other with wide needle and light stasis. Abscissa and ordinate as in Fig. $\mathbf{I}$.
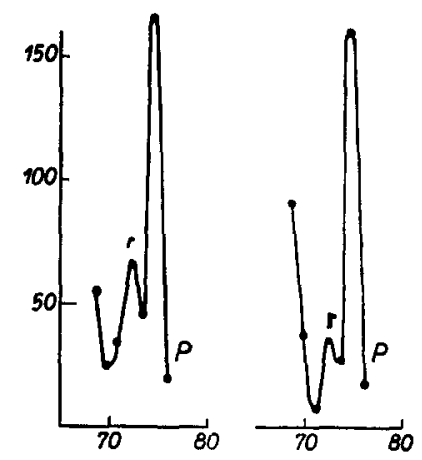

Fig. 3. As Fig. 2. but blood withdrawn slowly by narrow needle, with severe stasis.

As the establishment of a complete curve, with 50 points between $30 \%$ and $90 \%$ 3.5 $M$ phosphate solution, is a laborious procedure, requiring 5 days, we resolved to investigate only part of the curve, to be able to examine at shorter intervals of time. We arbitrarily chose 8 points between 68.0 and $76.4 \% 3.5 M$ phosphate, corresponding to the region in which the less soluble albumins precipitate. Most experiments were performed at these salt concentrations, but several experiments at other salt concentrations, in the globulin zone, showed that the observations made in the first-mentioned zone are also valid for the rest of the curve. 
It was established that when blood is withdrawn rapidly from the vein, using a wide needle, and with light stasis, plasma prepared from 2 samples of blood taken directly one after the other gives identical diagrams (Fig. 2). However, if the blood only emerges slowly, through a narrow needle, and stasis is severe, small differences already become apparent between the diagrams of plasma prepared from successively withdrawn samples (Fig. 3). So henceforward all work was done with blood collected in the manner first mentioned.
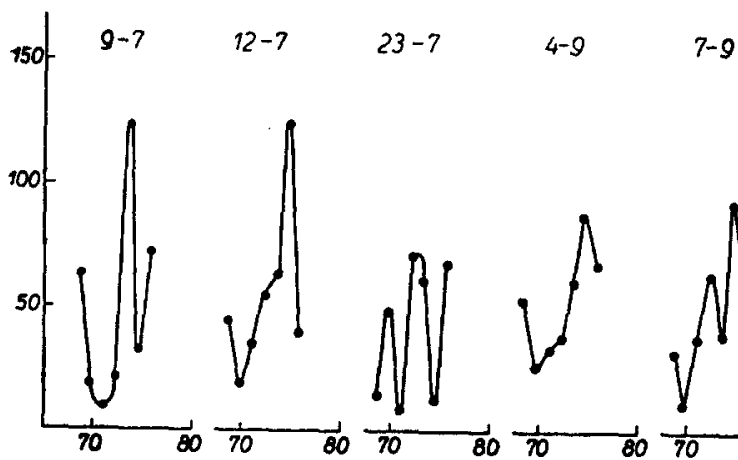

Fig. 4. Part of the curves of plasma obtained from one person on different days. Abscissa and ordinate as in Fig. I.
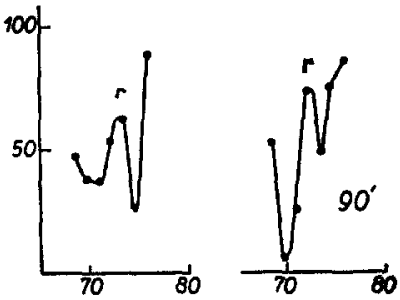

Fig. 5. Part of the curves of plasma obtained from one person with an interval of 90 minutes. Abscissa and ordinate as in Fig. 1 .

Diagrams of plasma were now made of some persons with intervals of several days, and Fig. 4 gives an example of the great differences that were observed between the diagrams of one person. Not only with an interval of days, but also with an interval of $\mathrm{I} 1 / 2$ or 2 hours the picture had already changed (Fig. 5).

Do these differences reflect the dynamic state of the plasma proteins as they circulate or are the diagrams we obtain also a reflection of other influences, e.g. our treatment in procuring the plasma (or serum), or variation of non-protein factors in the plasma?

To examine the first point, the influence of the manner of preparing plasma, we first investigated the influence of the anti-coagulant used. The same plasma diagram was obtained, whether $0.25 \%$ or $0.5 \%$ sodium citrate was added to the blood, but if

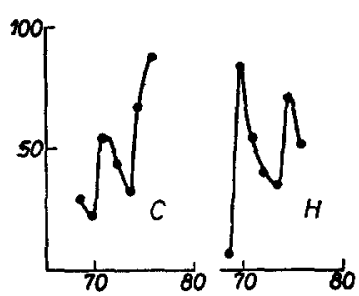

Fig. 6. Part of the curves of two samples of plasma obtained from blood withdrawn at one time, but treated with a different anti-coagulant. $\mathrm{C}=0.3 \%$ citrate $; \mathrm{H}=$ $0.03 \%$ heparin. Abscissa and ordinate as in Fig. $I$.

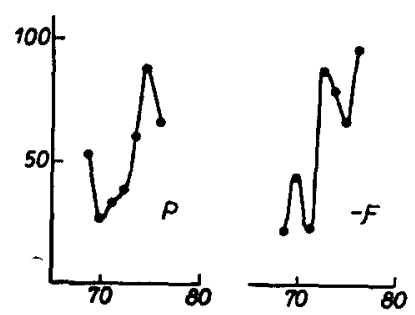

Fig. 7. Part of the curves of plasma and of serum obtained by defibrination, prepared from blood withdrawn at one time. $\mathbf{P}=$ plasma, $-F=$ serum from defibrinated blood. Abscissa and ordinate as in Fig. 1.

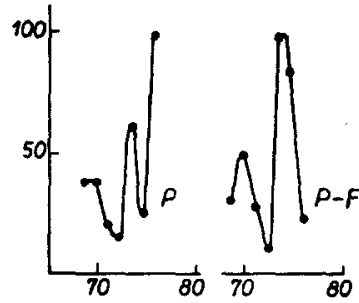

Fig. 8. Part of the curves of plasma and of the same plasma after defibrination with a trace of thrombin. $\mathrm{P}=$ plasma, $\mathrm{P}-\mathrm{F}=$ defibrinated plasma. Abscissa and ordinate as in Fig. I. 
Io $\mathrm{mg}$ heparin were added to $30 \mathrm{ml}$ blood instead of Ioo $\mathrm{mg}$ sodium citrate, a completely different picture resulted (Fig. 6). So the nature of the anti-coagulant definitely seems to influence the salting-out diagram.

If from two samples of blood, withdrawn at the same time, plasma is prepared in one case and serum in the other, the diagrams obtained are mutually different, whether the serum be prepared by allowing the blood to clot or by defibrination by stirring with a glass rod. Fig. 7 gives an example; here plasma is compared to serum obtained by defibrination. The remarkable fact was always observed that the total nitrogen content of serum is higher than that of the corresponding plasma. One would expect the contrary to be the case, for serum no longer contains the protein fibrinogen, but apparently relatively more water is removed with the fibrin.

When one sample of plasma is divided into two portions and fibrin is removed from one of these by stirring after adding a trace of thrombin, so little that the nitrogen thus added cannot be detected in the usual analysis, the diagram changes (Fig. 8).

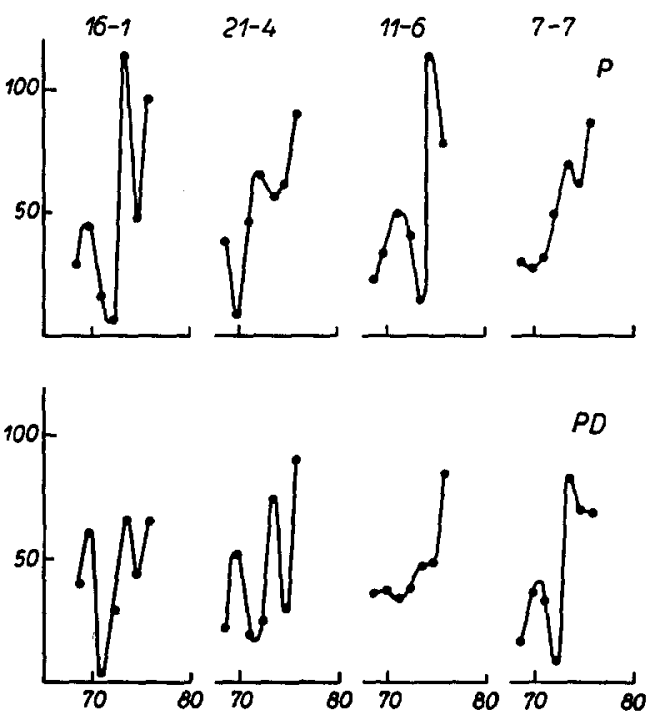

Fig. 9. Comparison of curves of plasma and of the same plasma after dialysis. Samples obtained from one person on different days. $P=$ plasma, $P D=$ dialyzed plasma. Abscissa and ordinate as in Fig. 1.

So removal of one of the protein components from the plasma also alters the picture of other components with quite different solubility (fibrinogen has its maximum of precipitation at $25 \% 3.5 \mathrm{M}$ phosphate).

To investigate the second point, influence of non-protein factors in the plasma upon the salting-out diagram of the proteins, plasma samples were divided into two portions. One portion was stored at $2^{\circ} \mathrm{C}$ while the other was dialyzed for 24 hours at $2^{\circ} \mathrm{C}$. This was done several times with plasma obtained from the same individual. Fig. 9 gives the result of these experiments. On each day there is a marked difference between the diagrams of dialyzed and undialyzed plasma, but also the picture of dialyzed plasma changes from day to day. This variability of the diagram of dialyzed plasma was also observed with blood of some other test persons, which was repeatedly investigated 
(Fig. Io). Neither was there any mutual resemblance between the diagrams of dialyzed plasma of these individuals.
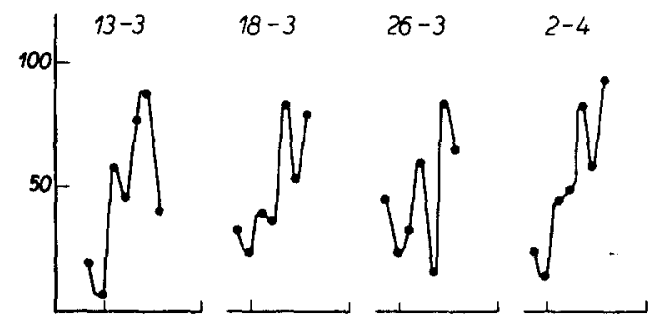

$7-4$
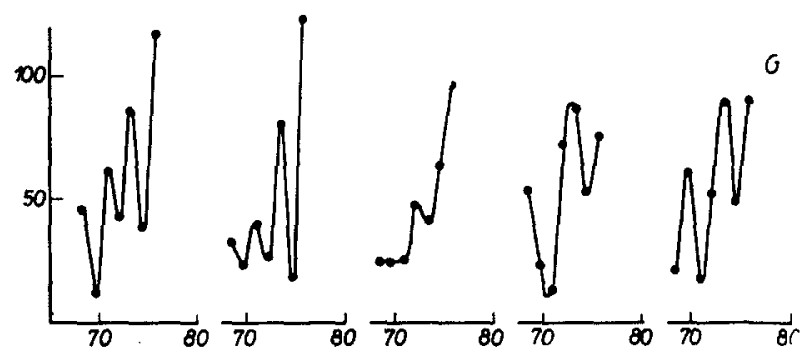

Fig. Io. Comparison of curves of dialyzed plasma obtained simultaneously from two persons, A. and $\mathrm{G}$., on different days. Abscissa and ordinate as in Fig. I.

\section{DISCUSSION}

The salting-out diagrams of human plasma do not just reflect the protein composition of the plasma, but their character is also markedly influenced by a number of other factors: the manner of obtaining the blood, the anti-coagulant, variability of non-protein components of the plasma; while diagrams of serum and plasma prepared from the same sample of blood also differ considerably from one another. The observation that the diagram of the other proteins changes when fibrinogen is removed from the plasma points to the extreme lability and interdependence of the plasma proteins.

These facts warn us to be very cautious when interpreting salting-out diagrams of plasma and serum, which cannot be considered to give solely a representation of the state of the plasma proteins.

But when the other factors are eliminated, by always withdrawing the blood in the same, correct, manner, using the same anti-coagulant, and dialyzing the plasma, the diagrams still change markedly from day to day, and these changes must reflect variations in protein composition. Curves of different normal individuals then also differ completely from one another. So we are left impressed by the very dynamic state in which the circulating plasma proteins proper appear to be.

Finally, this investigation has shown that the variability of salting-out diagrams of plasma proteins of normal individuals is much larger than it was thought to be, so it is well-nigh impossible to discern between small pathological deviations in protein composition of the plasma and normal variations.

\section{ACKNOWLEDGEMENTS}

The authors are very much indebted to Prof. H. G. K. Westenbrink, not only References p. 325 . 
for his interest and stimulating discussion, but also for his willingness to act as test person. Many thanks are also due to the other test persons: Messrs. Monfoort, Gruber, ALMA and GEMKE. This work could not have been done without the excellent assistance of Miss E. DEN HERTOG, who performed most of the analyses.

\section{SUMMARY}

Salting-out curves of proteins of normal human plasma reflect the influence of a number of other factors besides the protein composition: the manner of obtaining the blood, the nature of the anti-coagulant used, the non-protein components of the plasma.

Diagrams of serum and plasma obtained from one sample of blood are mutually different.

The diagram of dialyzed plasma, always prepared in the same manner, also changes with time in one individual, while no two persons have the same diagram. So the circulating plasma proteins appear to be in a highly dynamic state.

\section{RÉSUMÉ}

Les courbes de relargage des protéines du plasma humain normal refiètent, à part l'influence de la composition en protéines, celle d'un certain nombre de facteurs: la manière d'obtention du sang, la nature de l'anticoagulant employé, les composants non-protéiniques du plasma.

Les diagrammes de sérum et plasma d'une même prise de sang diffèrent entre eux.

Le diagramme de plasma dialysé, toujours préparé de la même manière, varie avec le temps chez un même individu et il n'y a pas deux personnes qui aient le même diagramme. Il semble donc que les protéines circulantes du plasma se trouvent dans un état hautement dynamique.

\section{ZUSAMMENFASSUNG}

Aussalzkurven von Proteinen des normalen menschlichen Plasmas spiegeln den Einfluss einer Reihe anderer Faktoren ausser der Proteinzusammensetzung wider: den der Art der Blutgewinnung, der Natur des benützten gerinnungshemmenden Stoffes und den der Nicht-Proteinbestandteile des Plasmas.

Serum- und Plasmadiagramme, die von einer Probe Blut erhalten wurden, sind von einander verschieden.

Das Diagramm von dialysiertem, immer in der gleichen Weise hergestellten Plasma ändert sich ebenfalls mit der Zeit bei einem Individium und nicht zwei Personen haben das gleiche Diagramm. Die zirkulierenden Plasmaproteine scheinen sich daher in einem höchst dynamischen Zustand zu befinden.

\section{REFERENCES}

1 Y. Derrien, Biochim. Biophys. Acta, 8 (I952) 63 I.

2 Y. Derrien, E. P. Steyn Parve, M. Cotte And G. Laurent, Biochim. Biophys. Acta, 9 (1952) 49.

3 Y. DeRrien, Svensk Kemisk Tidskr., 59 (I947) I39. 